\title{
NOD-2 and TLR-4 Signaling Reinforces the Efficacy of Dendritic Cells and Reduces the Dose of TB Drugs against Mycobacterium tuberculosis
}

\author{
Nargis Khan Susanta Pahari Aurobind Vidyarthi Mohammad Aqdas \\ Javed N. Agrewala \\ Institute of Microbial Technology, Council of Scientific and Industrial Research, Chandigarh, India
}

\section{Key Words}

Mycobacterium tuberculosis · Immunomodulation · NOD-2 ·

TLR-4 · Isoniazid · Rifampicin · Dendritic cells
In the future, adjunct therapy involving NOD-2L, TLR-4L and TB drugs may have enough potential to reduce the dose and duration of treatment of TB patients. @ 2015 s. Karger AG, Basel

\begin{abstract}
Tuberculosis (TB) is one of the leading killer infectious diseases. TB patients are inflicted with devastating side effects and the toxicity of a lengthy drug regime, accentuating an urgent need to explore newer and safer treatment methods. Recently, an improved understanding of host-pathogen interaction has opened new avenues for TB treatment, including immunotherapy. This has emboldened us to devise a novel strategy to restrict Mycobacterium tuberculosis (Mtb) growth by activating dendritic cells (DCs) through the NOD2 and TLR-4 molecules of innate immunity. Triggered DCs show a robust release of cytokines and nitric oxide, autophagy and improved migration towards the lymph nodes, and consequently impede the intracellular survival of $M t b$. Of note, this approach enhanced the efficacy of TB drugs by reducing their dose to a 5-fold lesser concentration than recommended. In vivo administration of ligands of NOD-2 (NOD-2L) and TLR-4 (TLR-4L) substantially increased the pool of effector memory CD4 and CD8 T cells. Additionally, NOD-2L and TLR-4L, in conjunction with the reduced dose of isoniazid, substantially declined the Mtb burden in the lungs.
\end{abstract}

\section{Introduction}

Despite the availability of highly effective drug regimens, tuberculosis (TB) continues to wreck public health worldwide. Furthermore, the threat is compounded by the emergence of the AIDS pandemic and drug-resistant strains of Mycobacterium tuberculosis (Mtb) [1]. The bacillus Calmette-Guérin (BCG) vaccine is available against $\mathrm{TB}$, but its role is highly controversial due to its variable efficacy globally [2]. Hence, there is an urgent need to develop innovative strategies to treat TB. Since recently, novel therapies employing immunomodulators are being explored for treating various ailments such as cancer, autoimmunity and cardiac diseases [3-6]. Immunotherapy holds great promise for various diseases, but no serious effort has been undertaken in the case of TB.

Adaptive immunity plays a vital role against $M t b$ due to its specificity and memory response. However, in the last few decades, the focus has been generated more on innate immunity. Innate cells perform multiple functions

\section{KARGER}

(c) 2015 S. Karger AG, Basel

$1662-811 \mathrm{X} / 15 / 0083-0228 \$ 39.50 / 0$

E-Mail karger@karger.com

www.karger.com/jin
Dr. Javed N. Agrewala

Institute of Microbial Technology, CSIR

Sector 39A

Chandigarh 160036 (India)

E-Mail javed@imtech.res.in 
employing various pattern recognition receptors such as Toll-like receptors (TLRs), C-type lectin receptors and Nod-like receptors (NLRs) [7, 8]. Recently, the experimental model of TB has highlighted the importance of TLRs in protecting against $M t b$ [9]. TLRs contribute substantially in resistance against $M t b$, but this attribute is not endowed to their function alone. Furthermore, the recognition of antigens by NOD-2 (nucleotide-binding oligomerization domain 2), a member of the NLR family also critically contributes in imparting immunity against bacteria or viruses [10-12]. This indicates that synergistic triggering through TLRs and NOD-2 may result in a stronger and enduring immune response that could restrict the growth of $M t b$. The WHO has also recommended the use of immunomodulators as an adjunct therapy to the existing TB drugs [13].

Dendritic cells (DCs) are the most potent antigen presenting cells that activate naive T cells. Despite their key role in initiating cell-mediated immunity, DCs exhibit several deficiencies including inferior bactericidal activity and limited migration to the draining lymph nodes (DLNs) [14]. Noteworthy, DCs are the major players in bridging innate and adaptive immunity. Targeting DCs in order to improve their bactericidal activity could strengthen both innate and adaptive immunity. Taking into consideration the above-mentioned facts, we designed an innovative approach to bolster DC efficacy by delivering signals via NOD-2 and TLR- $4\left(\mathrm{~N}_{2} \mathrm{~T}_{4}\right)$. It is important to mention that NOD-2 is expressed in the cytoplasm. To ligate with receptors, a ligand for NOD-2 is internalized into acidified vesicles by endocytosis dependent on the clathrin and dyamin pathways [15]. We selected N-glycolyl muramyl dipeptide (MDP) as a NOD-2 agonist as it exhibits 10 to 100 fold more potent immunogenicity than the commonly studied N-acetylated MDP [16]. We used LPS as a source of TLR-4 ligand (TLR-4L). Recently, the FDA has approved the use of LPS in medicines, which has opened new avenues to harness its remedial potential $[17,18]$. DCs activated by signaling through NOD-2 and TLR-4 ( $\mathrm{N}_{2} \mathrm{~T}_{4}$.DCs) exhibited improvement in bactericidal activity. Further, $\mathrm{N}_{2} \mathrm{~T}_{4}$ triggering afforded a favorable window for TB drugs to achieve an optimum immune response against $M t b$. Importantly, $\mathrm{N}_{2} \mathrm{~T}_{4}$.DCs required a considerably lesser dose of the drug to kill the $M t b$. Activated DCs also induced a better T cell response in vivo due to improved migration and augmented autophagy. This study may open new avenues of adjunct therapy employing drugs in combination with signaling through NOD-2 and TLR-4 in successfully treating TB.

\section{Material and Methods}

\section{Animals}

C57BL/6 mice, 6-8 weeks of age, were procured from the institute's animal facility. All experiments were approved by the Institutional Animal Ethics Committee (No. 55/1999/CPCSEA), Ministry of Environment and Forests, Government of India.

\section{Antibodies and Reagents}

All standard chemicals and reagents used in the study were purchased from Sigma (St. Louis, Mo., USA), and antibodies and recombinant cytokines from BD Biosciences (San Diego, Calif., USA) unless stated otherwise. TLR-4L, i.e. LPS, and NOD-2 ligand (NOD-2L), i.e. N-glycolyl MDP, were procured from Invitrogen (San Diego, Calif., USA). Anti-mouse LC-3 and inducible nitric oxide synthase (iNOS) antibodies were obtained from Sigma and Abcam (Cambridge, UK), respectively.

\section{Mycobacterial Strain and Antigens}

Mtb strains (H37Rv and H37Ra) were provided by Dr. V.M. Katoch, National JALMA Institute for Leprosy and Other Mycobacterial Diseases, India, and Salmonella typhimurium was provided by Dr. Amitabha Mukhopadhyay, National Institute of Immunology, India. $M t b$ was cultured in Middlebrook 7H9 broth containing glycerol $(0.2 \%)$ and Tween-80 (0.05\%) supplemented with albumin, dextrose and catalase. The viability of the bacteria was determined by plating on Middlebrook 7H11 medium supplemented with oleic acid, albumin, dextrose and catalase, and then counting the number of colony-forming units (CFU). S. typhimurium was cultured in LB broth. Viability was determined by plating on LB agar medium.

Culture of Bone Marrow-Derived DCs and Their Stimulation via NOD-2 and TLR-4

Bone marrow-derived DCs were cultured according to Lutz et al. [19]. Briefly, bone marrow cells (BMCs) were flushed aseptically from femurs and tibias. For DC cultures, cells were grown in RPMI 1640 (Invitrogen, Life Technologies, Eugene, Oreg., USA) containing FCS (10\%; Gibco, Grand Island, N.Y., USA) supplemented with penicillin $(100 \mathrm{U} / \mathrm{ml})$, streptomycin $(100 \mathrm{mg} / \mathrm{ml}), \mathrm{L}-$ glutamine $(100 \mathrm{mM})$, granulocyte-macrophage colony-stimulating factor (GM-CSF) $(2 \mathrm{ng} / \mathrm{ml})$ and murine r-IL-4 $(4 \mathrm{ng} / \mathrm{ml})$ for 6 days. Cultures were maintained in a humidified atmosphere and $5 \% \mathrm{CO}_{2}$ at $37^{\circ} \mathrm{C}$. The medium was replenished on day 3 . DCs were then harvested, washed and stimulated with N-glycolyl MDP (10 $\mu \mathrm{g} / \mathrm{ml}$ ) and LPS (5 $\mathrm{ng} / \mathrm{ml})$, respectively, for $24 \mathrm{~h}$.

For macrophages, BMCs were grown in RPMI $1640+$ FCS and replenished with L929 (20\%) supernatant, as a source of M-CSF. Later, macrophages were harvested, washed and stimulated with NOD-2L $(10 \mu \mathrm{g} / \mathrm{ml})$ and TLR-4L $(10 \mathrm{ng} / \mathrm{ml})$ for $24 \mathrm{~h}$.

\section{In vitro Infection with Bacteria and CFU Assay}

Bacterial aliquots were rapidly thawed, washed $2 \times$ with PBS and resuspended in RPMI $1640+$ FCS. To remove clumps, bacteria were passed through an insulin syringe. DCs were infected with the indicated multiplicity of infection (MOI). Cells were infected with Mtb for $4 \mathrm{~h}$ (MOI 1:5) and with Mycobacterium smegmatis for $3 \mathrm{~h}$ (MOI 1:5). After infection, cells were washed extensively to remove extracellular bacteria, and were then further incubated with NOD-2L and TLR-4L for 24 and $72 \mathrm{~h}$ with the mycobacteria 
in the presence of amikacin $(2 \mu \mathrm{g} / \mathrm{ml})$. After 24 or $72 \mathrm{~h}$, cell supernatants were removed, saponin $(0.1 \%)$ was added to lyse the cells and plating was done with $10 \times$ serial dilution on a $7 \mathrm{H} 11$ agar plate. The colonies were enumerated at 3 days and 3 weeks for $M$. smegmatis and $M t b$, respectively, after the incubation at $37^{\circ} \mathrm{C}$ in a humidified $\mathrm{CO}_{2}(5 \%)$ atmosphere. Where indicated, isoniazid (INH; $25 \mu \mathrm{g} / \mathrm{ml}$ ), rifampicin (RIF; $0.5 \mu \mathrm{g} / \mathrm{ml}$ ) or the iNOS inhibitor Nmonomethyl-L-arginine (1 mM) was added, along with NOD-2L and TLR-4L, for $24 \mathrm{~h}$. For S. typhimurium experiments, DCs were infected with the bacterium (MOI 1:10) for $30 \mathrm{~min}$. After infection, cells were extensively washed and incubated for $1 \mathrm{~h}$ in cell culture medium containing gentamicin $(50 \mu \mathrm{g} / \mathrm{ml})$. The cells were washed and cultures were maintained in medium containing gentamicin $(10 \mu \mathrm{g} / \mathrm{ml})$ for $16 \mathrm{~h}$ in the presence or absence of NOD-2L and TLR-4L. For enumeration of the bacteria, cells were lysed with Triton X-100 (0.1\%) and serial dilution lysates were plated onto LB agar plates. To block autophagy, DCs were treated with the autophagy inhibitor wortmannin (for $2 \mathrm{~h}$ ) prior to $M t b$ infection, but chloroquine $(10 \mu \mathrm{M})$ was present throughout the culture $(24 \mathrm{~h})$.

\section{Nitric Oxide Production/Release}

Supernatants were harvested after $4 \mathrm{~h}$ of infection followed by stimulation via either NOD-2 or TLR- 4 or $\mathrm{N}_{2} \mathrm{~T}_{4}$ for $48 \mathrm{~h}$. The nitric oxide (NO) level was measured by the Griess method. Briefly, supernatants $(50 \mu \mathrm{l})$ were incubated with an equal volume of Griess reagent for $5 \mathrm{~min}$ at room temperature. Later, absorbance was measured at $595 \mathrm{~nm}$.

\section{Cytokine Assessment by ELISA}

The cytokines IL- 6 and IL- 12 were detected in culture supernatants at an indicated time point by standard ELISA, according to manufacturer's instructions.

\section{DC and T Cell Coculture}

$\mathrm{N}_{2} \mathrm{~T}_{4}$.DCs (C57BL/6) were cocultured with magnetic-associated cell sorted (98\%) purified CD4 T cells (BALB/c) at a ratio of 1:5. After $72 \mathrm{~h},{ }^{3} \mathrm{H}$-thymidine $(0.5 \mu \mathrm{Ci} /$ well $)$ was added to the cultures. The plates were harvested after $16 \mathrm{~h}$ and the radioactivity incorporated into the cells was measured as counts/min (cpm) by scintillation counting. In parallel, cultures were set for $48 \mathrm{~h}$ for cytokine assessment (IFN- $\gamma$ ) by ELISA and intracellular staining. For intracellular staining, cells were treated with PMA and ionomycin for $3 \mathrm{~h}$ followed by brefeldin for $2 \mathrm{~h}$ and then stained for IFN- $\gamma$.

\section{RT-qPCR for the Quantification of IFN- $\gamma$ and $i N O S$}

Total RNA was isolated by Trizol reagent from $M t b$-infected DCs stimulated via NOD-2, TLR- 4 or $\mathrm{N}_{2} \mathrm{~T}_{4}$ for $6 \mathrm{~h}$ or from the lungs of $M t b$-challenged mice, and followed by immunotherapy, according to the manufacturer's instruction (Invitrogen, Carlsbad, Calif., USA). RNA was quantified with the help of a NanoDrop spectrophotometer. A260/A280 ratio of all samples was in the range of 1.90-2.00. Intactness of RNA samples was determined with the help of formaldehyde denaturing agarose gel-electrophoresis. DNA contamination from RNA samples was removed by amplification grade DNase. Briefly, RNA samples $(1 \mu \mathrm{g})$ were incubated with DNase ( $1 \mathrm{U}$ ) for $15 \mathrm{~min}$ in the reaction buffer. After the incubation, DNase activity was terminated by stop solution. The samples were then heated to $70^{\circ} \mathrm{C}$ for $10 \mathrm{~min}$ to inactivate DNase. Results are represented in the form of relative expression (fold) relative to untreated controls and placebo. Analysis was done by comparative $\mathrm{Ct}$ method, with $\mathrm{Ct}$ values normalized against housekeeping control actin. Using the comparative $\mathrm{Ct}$ method, relative gene expression was calculated as $2\left({ }^{-\Delta \Delta} \mathrm{Ct}\right)$, where $\Delta \mathrm{Ct}=$ $\mathrm{Ct}$ (gene of interest) $-\mathrm{Ct}$ (normalizer $=\beta$-actin $)$ and the $\Delta \Delta \mathrm{Ct}=$ $\Delta \mathrm{Ct}$ (sample) $-\Delta \mathrm{Ct}$ (calibrator). The calibrator was total RNA from placebo-treated lungs. RT-qPCR and data analysis were done with a Realplex Mastercycler (Eppendorf, Hamburg, Germany).

IFN- $\gamma$ : fwd $5^{\prime}$-CTAAGCAAGGACGGCGAAT-3'; reverse $5^{\prime}$-TTCCACACTGCACCCACTT-3'

$\beta$-actin: fwd $5^{\prime}$-AGAGGGAAATCGTGCGTGAC-3'; reverse $5^{\prime}$-CAATAGTGATGACCTGGCCGT-3'

iNOS: fwd 5'-AACGGAGAACGTTGGATTTG-3'; reverse 5'-CAGCACAAGGGGTTTTCTT-3'.

\section{Propidium Iodide and Annexin V Assays}

DCs were stimulated through NOD-2, TLR- 4 or $\mathrm{N}_{2} \mathrm{~T}_{4}$ at $37^{\circ} \mathrm{C}$ and $5 \% \mathrm{CO}_{2}$ for $24 \mathrm{~h}$. This was followed by resuspension of the cells in binding buffer (0.01 M HEPES, $\mathrm{pH} 7.4,0.14 \mathrm{M} \mathrm{NaCl}$ and $2.5 \mathrm{mM}$ $\left.\mathrm{CaCl}_{2}\right)$. FITC-conjugated annexin $\mathrm{V}(5 \mu \mathrm{l} /$ tube $)$ and $5 \mu \mathrm{l}$ of propidium iodide $(50 \mu \mathrm{g} / \mathrm{ml})$ were added to the cells and incubated in the dark for $15 \mathrm{~min}$ at room temperature. Later, binding buffer $(400 \mu \mathrm{l})$ was added and cells were acquired immediately, employing a BD FACS Calibur flow cytometer; analysis was done using BD DIVA software.

\section{Western Blotting}

$M t b$-infected DCs were stimulated through NOD-2, TLR- 4 or $\mathrm{N}_{2} \mathrm{~T}_{4}$ for $2 \mathrm{~h}$. Later, cells were harvested, washed and lysed in lysis buffer (RIPA buffer, protease and phosphatase inhibitor cocktail). Proteins in the supernatants were estimated and an equal concentration was subjected to SDS-PAGE. After transfer to the nitrocellulose membrane and subsequent blocking, the membranes were immunoblotted with antibodies against LC3-I/LC3-II and actin as a loading control. Blots were developed using a chemiluminescence kit (Amersham Pharmacia Biotech, Amersham, UK). Blots were scanned with the help of a phosphoimager (Fujifilm, Tokyo, Japan) and image analysis was performed with MultiGauge software. For iNOS, $M t b$-infected DCs were stimulated through NOD2, TLR- 4 or $\mathrm{N}_{2} \mathrm{~T}_{4}$ for $16 \mathrm{~h}$ and the expression was analyzed by Western blotting.

\section{Flow Cytometric Analysis for the Expression of}

Activation Markers

$M t b$-infected or uninfected DCs stimulated with NOD-2 and TLR- 4 in the presence or absence of IL-12-neutralizing antibodies for $24 \mathrm{~h}$ were harvested and resuspended in staining buffer $(2 \%$ FCS, $2 \mathrm{mM} \mathrm{NaN}_{3}$ in PBS). To block nonspecificity, cells were first incubated with Fc block (anti-CD16/32 Ab) for 25 min at $4{ }^{\circ} \mathrm{C}$. The cells were washed and then stained with fluorochrome-conjugated antibodies specific for CCR7, and the control cells with isotypematched antibodies for $30 \mathrm{~min}$ at $4^{\circ} \mathrm{C}$. Cells were washed and fixed with paraformaldehyde $(1 \times)$. Data were collected using FACS ARIA II and analyzed with BD DIVA software.

\section{siRNA Knockdown of NOD-2}

DCs were incubated with NOD-2 siRNA $(1 \mu \mathrm{M})$ in Accell siRNA delivery media, as per the manufacturer instructions (Thermo-Scientific Dharmacon). After $48 \mathrm{~h}$, inhibition in the expression of NOD-2 was detected at mRNA level by RT-qPCR. 
For functional assays, DCs incubated with NOD-2 siRNA for $72 \mathrm{~h}$ were washed and restimulated with $\mathrm{N}_{2} \mathrm{~T}_{4} \mathrm{~L}$ in RPMI + FCS for $24 \mathrm{~h}$. Later, IL- 6 production was detected in supernatants by ELISA.

Migration of DCs in vivo

DCs were infected with $M t b$ followed by stimulation through $\mathrm{N}_{2} \mathrm{~T}_{4}$ for $24 \mathrm{~h}$. Later, $\mathrm{N}_{2} \mathrm{~T}_{4}$. DCs $\left(3 \times 10^{6}\right.$ cells $)$ were labeled with CFSE $(5 \mu \mathrm{M})$ and adoptively transferred into mice. After $72 \mathrm{~h}$, the mice were sacrificed, the DLNs were isolated and a single-cell suspension was prepared. The frequency of CFSE-positive cells was quantified employing flow cytometry.

\section{Therapeutic Strategy}

Mice were aerosol-challenged with $M t b$, and $100 \mathrm{CFU}$ were deposited in the lungs. Later, the animals were injected twice subcutaneously with a gap of 15 days with $\mathrm{N}_{2} \mathrm{~T}_{4} \mathrm{~L}$ and the controls with NOD-2L or TLR-4L. The dose of NOD-2L versus TLR-4L for an in vivo assay was selected on the basis of the reduction in CFU in the lungs of $M t b$-challenged animals treated with different doses of NOD-2L (3, 30 and $300 \mu \mathrm{g} / 100 \mu \mathrm{l}$ PBS) or TLR-4L $(0.1,1$ and $10 \mu \mathrm{g} / 100 \mu \mathrm{l}$ PBS ) alone or in combination, twice with a gap of 15 days. After the last injection, the animals were sacrificed and CFU were determined in the lungs. Total CFU per gram of lung were calculated. The optimum reduction in CFU was noticed with $3 \mu \mathrm{g} /$ $100 \mu \mathrm{l}$ of NOD-2L and $0.1 \mu \mathrm{g} / 100 \mu \mathrm{l}$ of $\mu \mathrm{l}$ TLR-4L, so these doses were selected to perform all in vivo experiments.

\section{Isolation of Lymphocytes}

Mice were aerosol-challenged with $M t b$ followed by treatment with NOD-2L, TLR-4L or $\mathrm{N}_{2} \mathrm{~T}_{4} \mathrm{~L}$. After 45 days of aerosol challenge with $M t b$, the mice were sacrificed. The lungs were perfused and the spleen and lymph nodes (mediastinal) were harvested and a single-cell suspension was prepared. Briefly, lymphocytes from the spleen were prepared by lysis of red blood cells with ACK lysing buffer $\left(0.15 \mathrm{M} \mathrm{NH}_{4} \mathrm{Cl}, 10 \mathrm{mM} \mathrm{KHCO}_{3}\right.$ and $88 \mathrm{~mm}$ EDTA), washed $3 \times$ with PBS and resuspended in RPMI $1640+$ FCS. Viability of the cells was assessed by the trypan blue dye exclusion method.

\section{Staining of the T Cell Surface Markers and Intracellular}

IFN- $\gamma$ Expression

Cells were incubated with Fc block for 25 min and stained for the expression of CD4, CD8, CD69, CD44 and CD62L by their respective antibodies. Cells were fixed in $1 \%$ paraformaldehyde. For intracellular expression, cells stained for the surface CD4 and CD8 molecules were fixed with $4 \times$ paraformaldeyde for $30 \mathrm{~min}$ followed by permeabilization with $0.01 \%$ saponin in PBS for $30 \mathrm{~min}$ at $4^{\circ} \mathrm{C}$. Later, cells were incubated with anti-IFN- $\gamma$ antibody in a staining buffer containing $0.01 \%$ saponin. The usual steps of washing were performed after each incubation. The control cells were stained with the respective isotype-matched antibodies. Cells were acquired in FACSAria II and analyzed with DIVA software.

\section{T Cell Proliferation}

Lymphocytes $\left(2.5 \times 10^{5}\right.$ cells/well $)$ were cultured in round-bottom, 96-well plates, in $200 \mu \mathrm{l}$ of RPMI $1640+$ FCS $10 \%$ and purified protein derivative (PPD; $6 \mu \mathrm{g} / \mathrm{ml}$ ) for $48 \mathrm{~h}$. Cells cultured with the medium alone (without antigen) were used as a control. Later, cultures were pulsed with $0.5 \mu \mathrm{Ci}$ of ${ }^{3} \mathrm{H}$-thymidine (Amersham Pharmacia Biotech). The plates were harvested after $16 \mathrm{~h}$ onto glassfiber filter mats using a Tomtec Harvester96 (Tomtec, Hamden,
Conn., USA). Radioactivity incorporated into the cells was measured by liquid scintillation spectroscopy utilizing Wallac 1450 MicroBeta TriLux (Perkin Elmer, Waltham, Mass., USA).

\section{Histopathology}

Mice were sacrificed and lung tissues were fixed in buffered formalin (10\%). Histological sections were stained using hematoxylin and eosin. Photomicrographs were captured on an Olympus IX71 microscope and displayed at $\times 40$ magnification.

\section{Statistical Analysis}

Data were analyzed by one-way analysis of variance (ANOVA) with the post-Tukey-Kramer multiple-comparison test by using GraphPad Prism software.

\section{Results}

\section{Signaling through $\mathrm{N}_{2} \mathrm{~T}_{4}$ Enhances the}

Activation of DCs

This study focused on improving DC efficacy by exploring their potency through $\mathrm{N}_{2} \mathrm{~T}_{4}$ signaling. We observed that DCs triggered through TLR-4 showed substantial production of IL-6 ( $\mathrm{p}<0.001)$ and IL-12 ( $\mathrm{p}<$ 0.001 ; fig. $1 \mathrm{a}, \mathrm{b}$ ). This effect was observed to be dose dependent. In contrast, triggering through NOD-2 failed to activate DCs, demonstrated by a lesser release of IL- 6 and IL-12. However, it was quite interesting to note that signaling of NOD-2 in conjunction with TLR-4, i.e. $\mathrm{N}_{2} \mathrm{~T}_{4}$, significantly enhanced the yield of both IL- $6(\mathrm{p}<0.01)$ and IL-12 ( $<<0.01$; fig. 1a, b). We observed the optimum release of IL-6 and IL- 12 with $10 \mu \mathrm{g} / \mathrm{ml}$ of NOD-2L and $5 \mathrm{ng} / \mathrm{ml}$ of TLR-4L. In contrast, $80 \mathrm{ng} / \mathrm{ml}$ of TLR- $4 \mathrm{~L}$ on its own induced a significantly lower release of IL- 6 ( $p<$ $0.01)$ and IL-12 ( $<<0.01)$. Hence, in all subsequent experiments, a dose of $10 \mu \mathrm{g} / \mathrm{ml} \mathrm{NOD}-2 \mathrm{~L}$ and $5 \mathrm{ng} / \mathrm{ml}$ TLR$4 \mathrm{~L}$ was selected. We also confirmed and validated the specificity of our results in DCs by knocking down the NOD-2 expression through siRNA $\left(\mathrm{N}_{2 \mathrm{KD}}\right.$; online suppl. fig. S1; see www.karger.com/doi/10.1159/000439591 for all online suppl. material) and, with its inhibitor CLI-095, blocking TLR-4 signaling $\left(\mathrm{T}_{4 \mathrm{i}}\right)$. Interestingly, compared to wild-type DCs, $\mathrm{N}_{2} \mathrm{~T}_{4}$ signaling showed no release by $\mathrm{N}_{2 \mathrm{KD}} \mathrm{T}_{4 \mathrm{i}}$.DCs (fig. 1c).

\section{$\mathrm{N}_{2} \mathrm{~T}_{4}$-Elicited DCs Showed Enhancement of T Cell \\ Proliferation and IFN- $\gamma$ Production}

$\mathrm{N}_{2} \mathrm{~T}_{4}$. DCs acquired a significantly $(\mathrm{p}<0.001)$ higher capacity to induce IFN- $\gamma$ production by allogeneic CD4 T cells, as corroborated by the ELISA and flow cytometry results (fig. 2a, b). Further, the improved performance of $\mathrm{N}_{2} \mathrm{~T}_{4}$. DCs was further authenticated by the substantial 


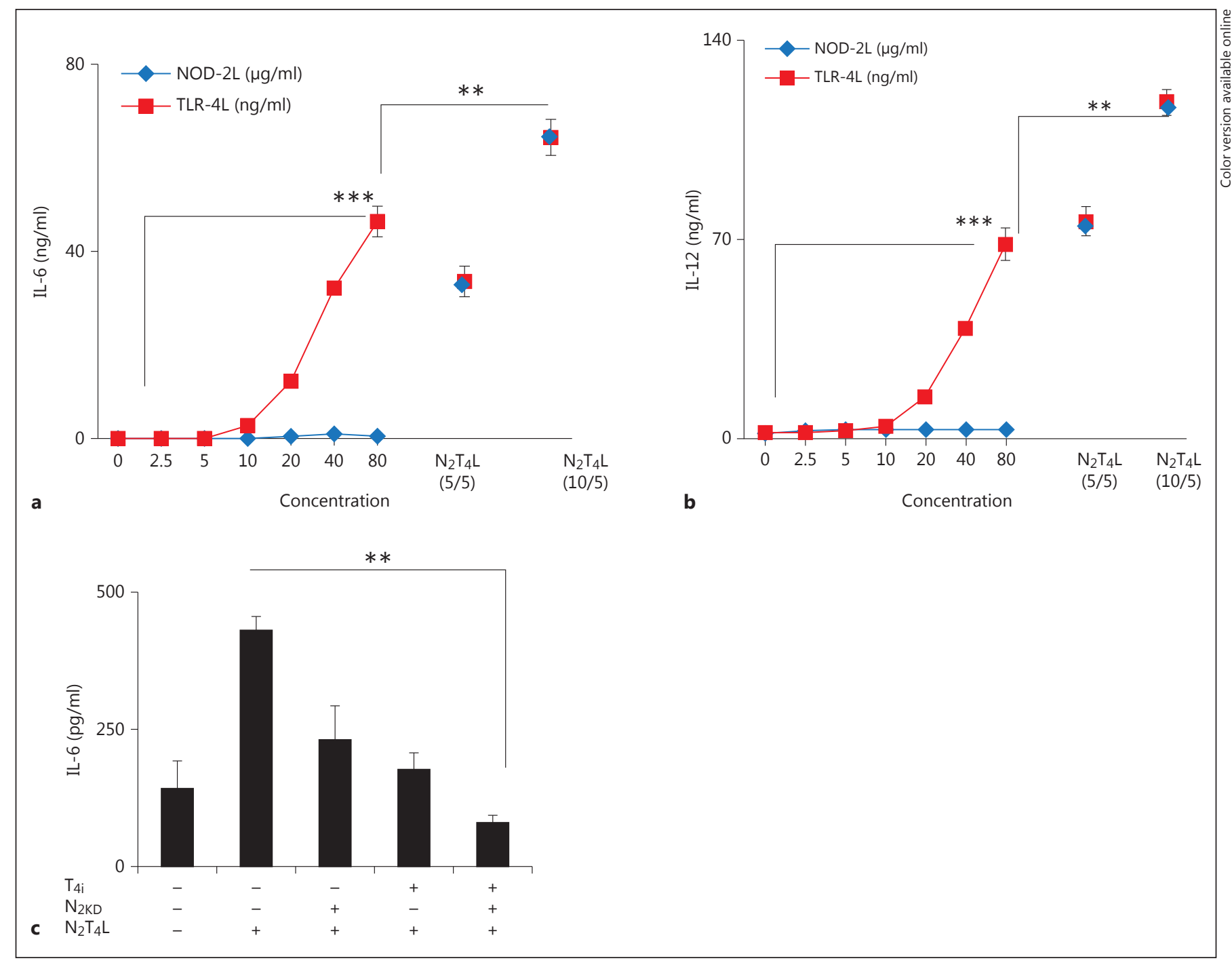

Fig. 1. Cumulative signaling through $\mathrm{N}_{2} \mathrm{~T}_{4}$ induces the maturation and activation of DCs. The bone marrow-derived DCs were stimulated with different doses of TLR-4L or NOD-2L. Later, culture supernatants were assessed for IL-6 (a) and IL-12 (b) cytokines by ELISA. The $\mathrm{x}$-axis shows the concentration of TLR-4L $(\mathrm{ng} / \mathrm{ml})$ and NOD-2L $(\mu \mathrm{g} / \mathrm{ml}) ;(5 / 5)$ indicates the concentrations $5 \mu \mathrm{g} / \mathrm{ml}$ NOD-2L and $5 \mathrm{ng} / \mathrm{ml}$ TLR-4L, and (10/5) indicates $10 \mu \mathrm{g} / \mathrm{ml}$

$(\mathrm{p}<0.0001)$ proliferation of T cells (fig. $2 \mathrm{c})$. These observations demonstrate that signaling of DCs through $\mathrm{N}_{2} \mathrm{~T}_{4}$ has a strong bearing on improving the activation of $\mathrm{T}$ cells.

Signaling of DCs through $\mathrm{N}_{2} \mathrm{~T}_{4}$ Restricted the

Intracellular Growth of Bacteria

Based on the above results, we subsequently monitored the bactericidal efficacy of the $\mathrm{N}_{2} \mathrm{~T}_{4}$.DCs. DCs infected
NOD-2L and $5 \mathrm{ng} / \mathrm{ml}$ TLR-4L. c DCs were knocked down for NOD-2 through siRNA. $\mathrm{N}_{2 \mathrm{KD}}$. DCs were stimulated with $\mathrm{N}_{2} \mathrm{~T}_{4}$ and cultured in the presence or absence of $\mathrm{TLR}_{4 \mathrm{i}}$ for $24 \mathrm{~h}$. Later, IL-6 was detected in culture supernatants. Data represented as mean \pm $\mathrm{SD}$ are of 3 experiments, each assayed in triplicate wells. ${ }^{* *} \mathrm{p}<0.01$, *** $\mathrm{p}<0.0001$, one-way ANOVA. 

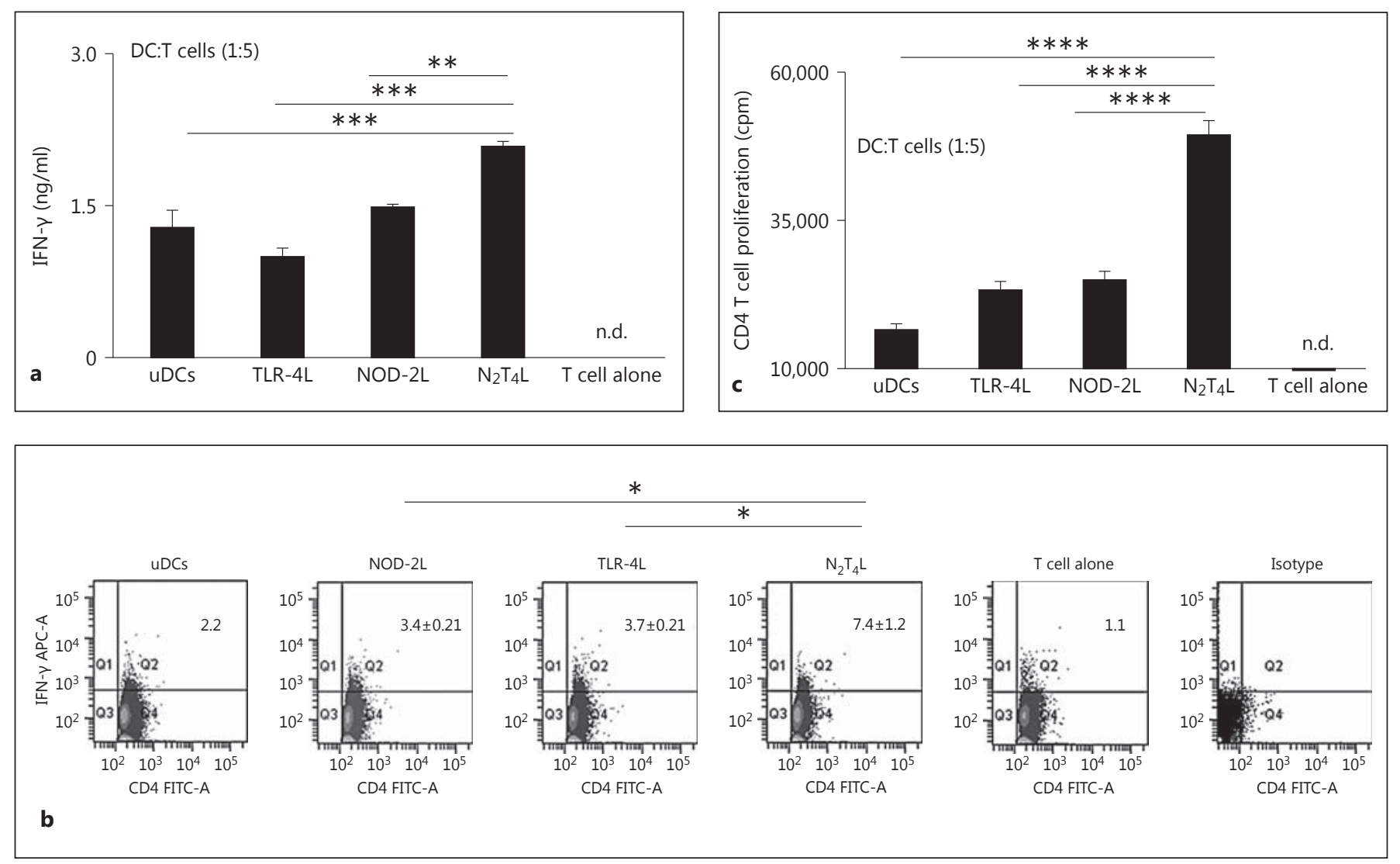

Fig. 2. Stimulation of DCs via $\mathrm{N}_{2} \mathrm{~T}_{4}$ bolsters their ability to enhance $\mathrm{T}$ cell proliferation and IFN- $\gamma$ production. $\mathrm{N}_{2} \mathrm{~T}_{4}$. DCs were cultured with allogeneic CD4 T cells for $48 \mathrm{~h}$ at a ratio of 1:5. a IFN- $\gamma$ was detected in the supernatants by ELISA. b Intracellular expression on flow cytometry. The data in the insets are the percentages of CD4/IFN- $\gamma$-positive T cells. $\mathbf{c}$ T cell proliferation was monitored by ${ }^{3} \mathrm{H}$-thymidine, and results are expressed as counts/min (cpm). Data represented as mean \pm SD are of 3 independent experiments. n.d. $=$ Not detected. ${ }^{*} \mathrm{p}<0.05,{ }^{* *} \mathrm{p}<0.01,{ }^{* * *} \mathrm{p}<0.001,{ }^{* * * *} \mathrm{p}<$ 0.0001 , one-way ANOVA.
Mtb (fig. 3a, b) but also M. smegmatis ( $<0.01$ ) and $S$. typhimurium ( $\mathrm{p}<0.05$; fig. $3 \mathrm{c}$; online suppl. fig. S5). It is important to mention here that the reduction in bacterial burden is not due to a differential uptake of $M t b$ by DCs. The bactericidal activity of DCs was demonstrated by first infecting DCs with bacteria for $4 \mathrm{~h}$. Later, infected DCs were stimulated through $\mathrm{N}_{2} \mathrm{~T}_{4}$. It was further confirmed by plating cell lysates of infected DCs at the initial time point (after $4 \mathrm{~h}$ ) of infection, which showed no difference in the uptake of $M t b$ (online suppl. fig. S2).

\section{$\mathrm{N}_{2} \mathrm{~T}_{4}$ Triggering of DCs Potentiated RIF and INH \\ Mediated the Killing of Mtb}

We also discerned that signaling of $M t b$-infected DCs through $\mathrm{N}_{2} \mathrm{~T}_{4}$ considerably boosted the killing efficacy of the anti-TB drugs RIF $(p<0.01)$ and INH $(p<0.01)$, when compared with the drugs alone (fig. 3d, e). Interestingly, $\mathrm{N}_{2} \mathrm{~T}_{4} \mathrm{~L}+\mathrm{RIF}$ and $\mathrm{N}_{2} \mathrm{~T}_{4} \mathrm{~L}+\mathrm{INH}$ showed a 75 and $60 \%$ reduction, respectively, in the bacterial burden when compared to RIF (37\%) or INH (46\%) alone. It may be concluded from these results that the adjunct therapy involving NOD-2L and TLR-4L in conjunction with INH and RIF may have an important implication in considerably improving the efficacy of anti-TB drugs to restrict the growth of $M t b$.

$\mathrm{N}_{2} \mathrm{~T}_{4}$.DCs Limited the Intracellular Survival of Mtb by Enhancing Autophagy and NO Production

It was important to elucidate the mechanism involved in restricting the survival of $M t b$ by $\mathrm{N}_{2} \mathrm{~T}_{4}$. DCs. Notably, we observed that inhibition of the growth of $M t b$ by $\mathrm{N}_{2} \mathrm{~T}_{4}$.DCs was operating through autophagy. This was 


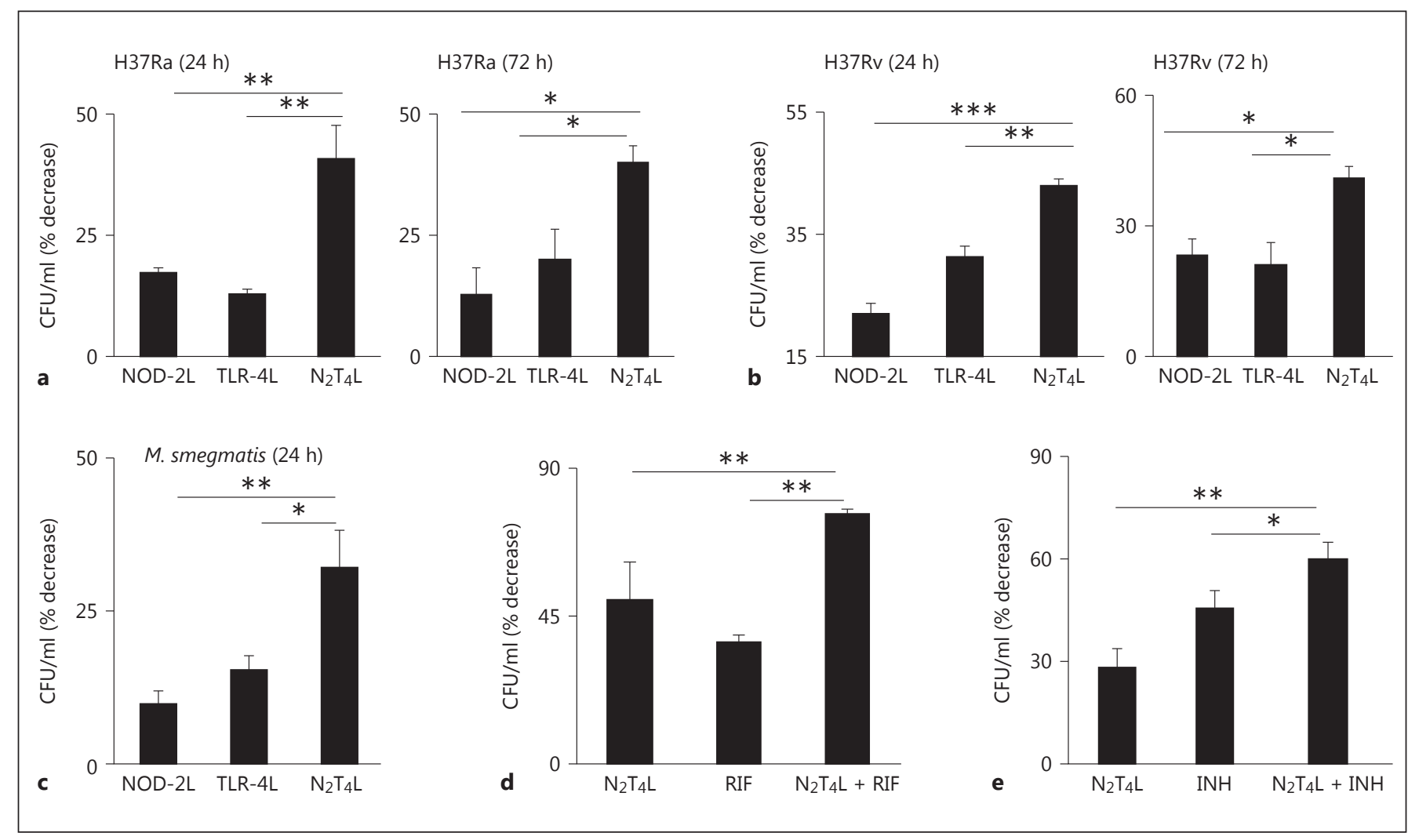

Fig. 3. Activation of DCs through $\mathrm{N}_{2} \mathrm{~T}_{4} \mathrm{~L}$ inhibits the replication of $M t b$ and potentiates the RIF- and INH-mediated killing. DCs were infected with $\mathrm{H} 37 \mathrm{Ra}$ (a), $\mathrm{H} 37 \mathrm{Rv}$ (b) and M. smegmatis (c) and then stimulated with $\mathrm{N}_{2} \mathrm{~T}_{4} \mathrm{~L}$ for 24 and $72 \mathrm{~h}$. The control DCs were cultured with TLR-4L or NOD-2L. The cells were lysed, and CFU were enumerated on day 3 or day 21. d, e DCs infected with Mtb were cultured with either $\mathrm{N}_{2} \mathrm{~T}_{4} \mathrm{~L}$ alone or in conjunction with RIF
$\left(\mathrm{N}_{2} \mathrm{~T}_{4} \mathrm{~L}+\mathrm{RIF}\right)$ or INH $\left(\mathrm{N}_{2} \mathrm{~T}_{4} \mathrm{~L}+\mathrm{INH}\right)$. Later, cells were lysed and CFU were enumerated on day 3 or day 21 and expressed as a percentage decrease. Decline in $M t b$ growth was monitored in response to RIF and INH. The bar diagram represents the mean \pm SEM of 3 experiments. ${ }^{*} \mathrm{p}<0.05,{ }^{* *} \mathrm{p}<0.01,{ }^{* * *} \mathrm{p}<0.001$, oneway ANOVA. demonstrated by the conversion of LC3-I to LC3-II (fig. 4a), which is a prominent indicator of autophagy [20]. This phenomenon was further confirmed by blocking autophagy, using its inhibitors wortmannin $(\mathrm{p}<0.01)$ or chloroquine $(\mathrm{p}<0.05)$, which significantly restored the survival of $M t b$ in $\mathrm{N}_{2} \mathrm{~T}_{4}$. DCs (fig. $4 \mathrm{~b}$ ).

We also discerned augmentation in the production of NO by $M t b$-infected $\mathrm{N}_{2} \mathrm{~T}_{4}$. DCs compared to control NOD-2L- or TLR-4L-treated DCs or untreated DCs (uDCs; fig. 4c). NO is an established indicator of bactericidal activity [21]. Furthermore, this finding was proved by quantifying the expression of iNOS by Western blotting and RT-qPCR (fig. 4d, e). It is important to mention here that $\mathrm{NO}$ release by $\mathrm{N}_{2} \mathrm{~T}_{4}$.DCs inhibited the survival of $M t b$. This information was confirmed by the CFU data. $\mathrm{N}_{2} \mathrm{~T}_{4}$.DCs failed to restrict $M t b$ growth in the presence of the iNOS inhibitor N-monomethyl-L-arginine (fig. $4 \mathrm{f}$ ). It can be concluded that $\mathrm{N}_{2} \mathrm{~T}_{4}$ triggering enhances the bactericidal activity of DCs by augmenting autophagy and NO release.

\section{Signaling through $\mathrm{N}_{2} \mathrm{~T}_{4}$ Enhances the Ability of}

\section{DCs to Migrate}

It is important that the activated DCs should capture antigens from the site of infection and migrate to the DLNs to activate naive T cells. Therefore, next, we studied the migratory capacity of $\mathrm{N}_{2} \mathrm{~T}_{4}$.DCs. Mtb-infected DCs activated through $\mathrm{N}_{2} \mathrm{~T}_{4}$ were CFSE-labeled and adoptively transferred into mice. It was observed that the frequency of $M t b$-infected CFSE-positive $\mathrm{N}_{2} \mathrm{~T}_{4}$.DCs in the DLNs was significantly $(\mathrm{p}<0.01)$ higher than unstimulated counterparts (fig. 5a). Similar results were noted in the uninfected $\mathrm{N}_{2} \mathrm{~T}_{4}$.DCs. 


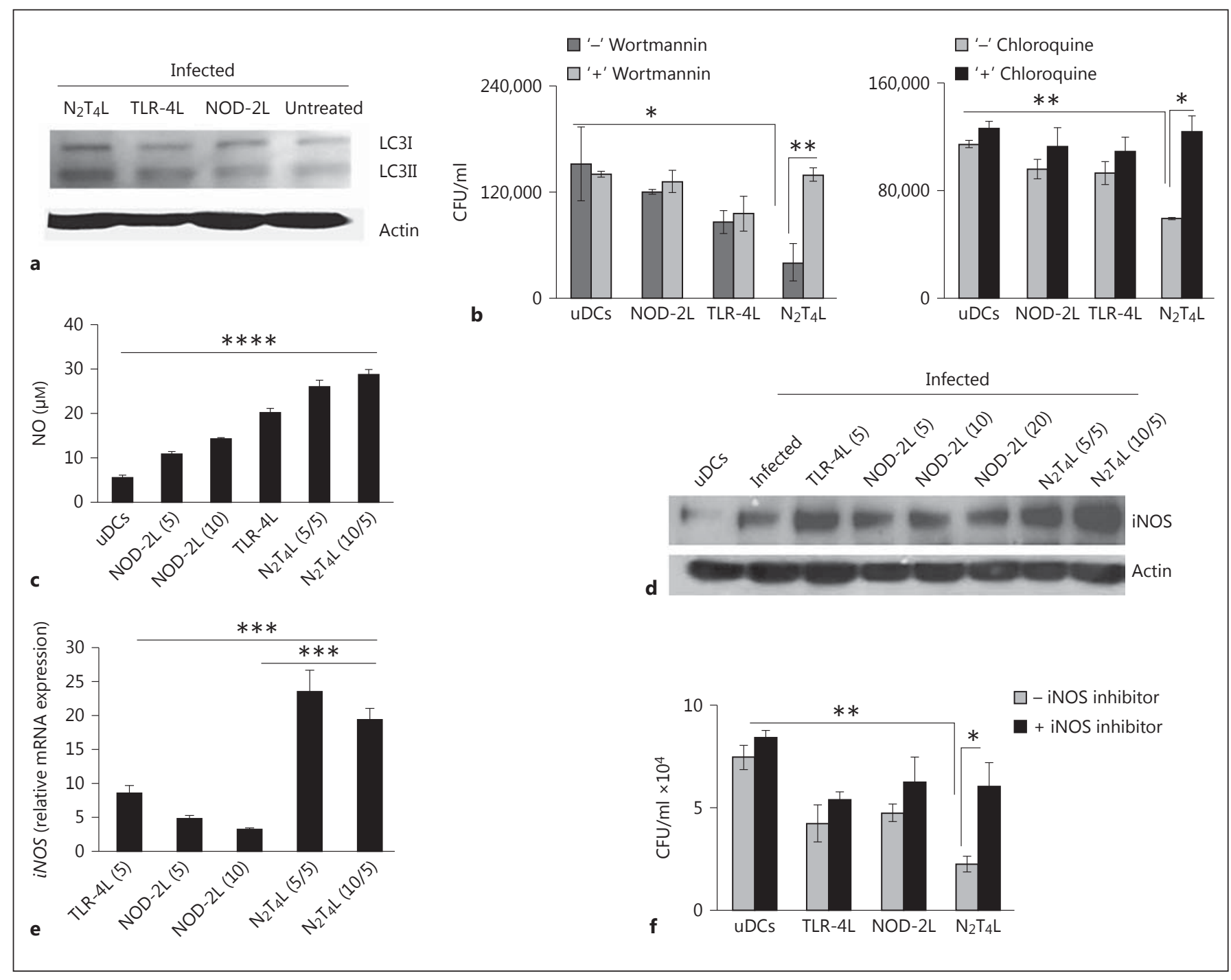

Fig. 4. Triggering DCs through $\mathrm{N}_{2} \mathrm{~T}_{4}$ induces autophagy and enhances the NO secretion. a DCs stimulated through $\mathrm{N}_{2} \mathrm{~T}_{4}$, TLR-4 or NOD-2 were monitored for the induction of autophagy through conversion of LC3I to LC3II. b DCs infected with $M t b$ were triggered through $\mathrm{N}_{2} \mathrm{~T}_{4}$ in the presence or absence of the autophagy inhibitors wortmannin and chloroquine for $24 \mathrm{~h}$. Later, bacterial burden was determined by CFU plating. DCs stimulated through $\mathrm{N}_{2} \mathrm{~T}_{4}$, TLR-4 or NOD-2 were monitored for NO in supernatants (c), iNOS by Western blotting (d) and $i N O S$ by RT-qPCR (e). The graph depicts the fold change in the expression of $i N O S$ compared to uDCs. The number in parentheses indicates the concentration of NOD-2L $(\mu \mathrm{g} / \mathrm{ml})$ or TLR-4L $(\mathrm{ng} / \mathrm{ml})$. f DCs infected with $M t b$ were stimulated through $\mathrm{N}_{2} \mathrm{~T}_{4}$ in the presence of iNOS inhibitor (N-monomethyl-L-arginine) for $24 \mathrm{~h}$. Later, the bacterial burden was determined through CFU plating. Data depicted as mean \pm SD or Western blots are representative of 2-3 independent experiments. ${ }^{*} \mathrm{p}<0.05,{ }^{* *} \mathrm{p}<0.01,{ }^{* * *} \mathrm{p}<0.001,{ }^{* * * *} \mathrm{p}<0.0001$, oneway ANOVA.
DCs stimulated through $\mathrm{N}_{2} \mathrm{~T}_{4}$ in vitro displayed upregulation of CCR7 (fig. 5b). CCR7 is responsible for the migration of DCs $[22,23]$. IL-12 is known to upregulate the expression of CCR7 [24]. We demonstrated earlier that $\mathrm{N}_{2} \mathrm{~T}_{4}$.DCs release greater amount of IL-12 (fig. 1b).
Importantly, we observed that neutralization of IL-12 by using anti-IL-12 antibody reduced the expression of CCR7 on $\mathrm{N}_{2} \mathrm{~T}_{4}$.DCs (fig. 5b). These data suggest that $\mathrm{N}_{2} \mathrm{~T}_{4}$-driven production of IL-12 by DCs upregulates the CCR7 expression on $\mathrm{N}_{2} \mathrm{~T}_{4}$. DCs. 


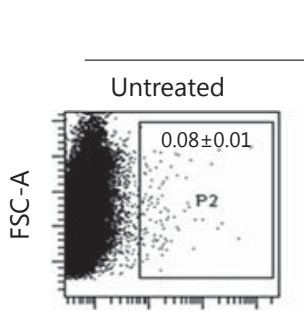

a

CFSE-H

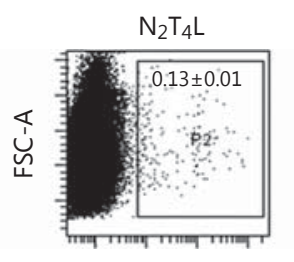

CFSE-H
$* *$

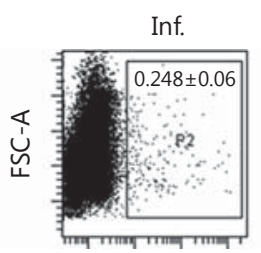

CFSE-H

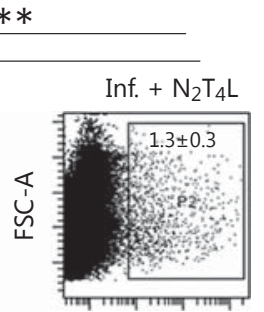

CFSE-H

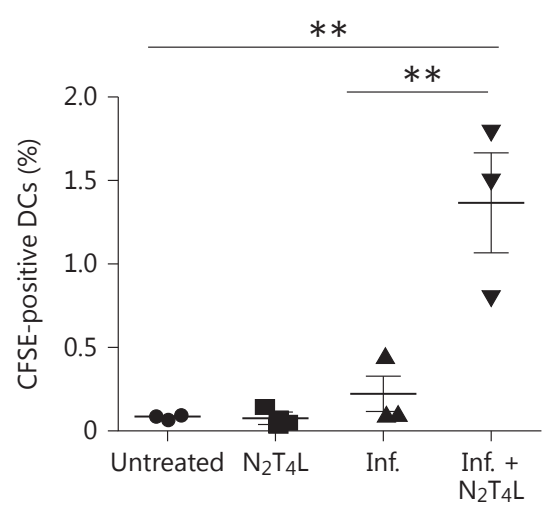

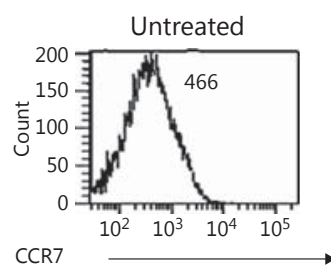

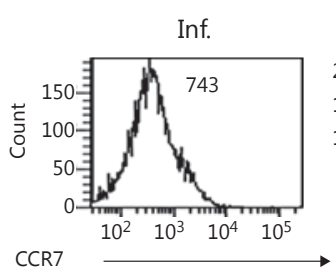

b
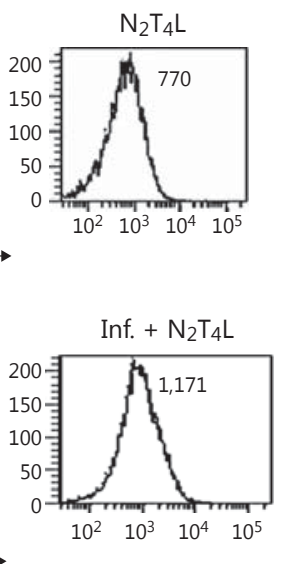

$\mathrm{N}_{2} \mathrm{~T}_{4} \mathrm{~L}+$ anti-IL-12
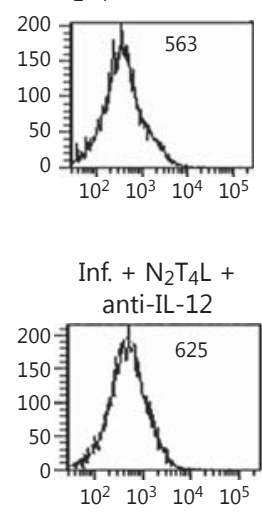
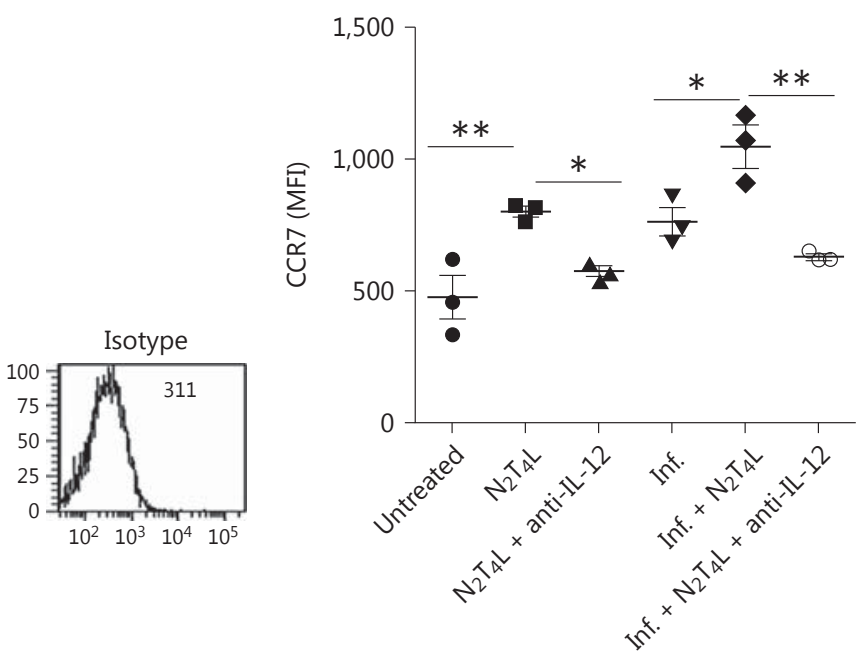

Fig. 5. $\mathrm{N}_{2} \mathrm{~T}_{4}$. DCs acquire enhanced in vivo migratory capability and capacity to prime naive T cells. DCs infected with Mtb were stimulated through $\mathrm{N}_{2} \mathrm{~T}_{4}$ for $24 \mathrm{~h}$. a The cells were labeled with CFSE prior to adoptive transfer into the mice. After 3 days, animals were sacrificed and $\mathrm{N}_{2} \mathrm{~T}_{4}$. DCs were tracked through flow cytometry in the DLNs. Data are expressed as dot plot and scatter graph for augmented migration (\%). b Elevated expression (MFI) of
CCR7 was assessed on $\mathrm{N}_{2} \mathrm{~T}_{4}$. DCs cultured in vitro for $24 \mathrm{~h}$. The results also show IL-12-mediated expression of CCR7, since neutralization of IL-12 with anti-IL-12 Abs reduces the expression of CCR7 on DCs. Each dot in the scattered plot indicates 1 mouse. Data represented as mean \pm SD are of 2 independent experiments with 3 mice/group. Inf. $=$ DCs infected with $M t b .{ }^{*} \mathrm{p}<0.05$, ** $\mathrm{p}<0.01$.
Immunization with NOD-2L and TLR-4L Bolsters the Immune Response and Reduces Mtb Burden

It was crucial for us to demonstrate the effectiveness of NOD-2L and TLR-4L in vivo to bolster the immune response and reduce the $M t b$ burden in the infected animals. It was observed that animals inoculated with $\mathrm{N}_{2} \mathrm{~T}_{4} \mathrm{~L}$ expressed significant enhancement in the CD69hi/CD $44^{\text {hi }}$ / CD62 $\mathrm{L}^{\text {lo }}$ phenotype on CD4 and CD8 T cells (fig. 6a, b), consequently supporting the generation of effector memory $\mathrm{T}$ cells. These animals also exhibited a better ex vivo percentage of IFN- $\gamma^{+}$CD4 $(\mathrm{p}<0.01)$ and CD8 $(\mathrm{p}<0.05)$ $\mathrm{T}$ cells (fig. $6 \mathrm{c}$ ). Furthermore, the elevated yield of IFN $-\gamma$ was confirmed by RT-qPCR in the lungs of $\mathrm{N}_{2} \mathrm{~T}_{4} \mathrm{~L}$-treated mice (fig. 6d). Similarly, in vitro stimulation of cells with PPD showed a considerable enhancement of IFN- $\gamma(\mathrm{p}<$ $0.001)$ production and displayed TNF- $\alpha^{+} \mathrm{CD} 4 \mathrm{~T}$ cells and $\mathrm{T}$ cell proliferation ( $\mathrm{p}<0.001$; fig. $6 \mathrm{e}-\mathrm{g}$ ).

$\mathrm{N}_{2} \mathrm{~T}_{4} \mathrm{~L}$-treated animals manifested better protective efficacy against $M t b$, as evident in the significant decline $(\mathrm{p}<0.001)$ of the $M t b$ burden in the lungs (fig. 7a). Fur- 

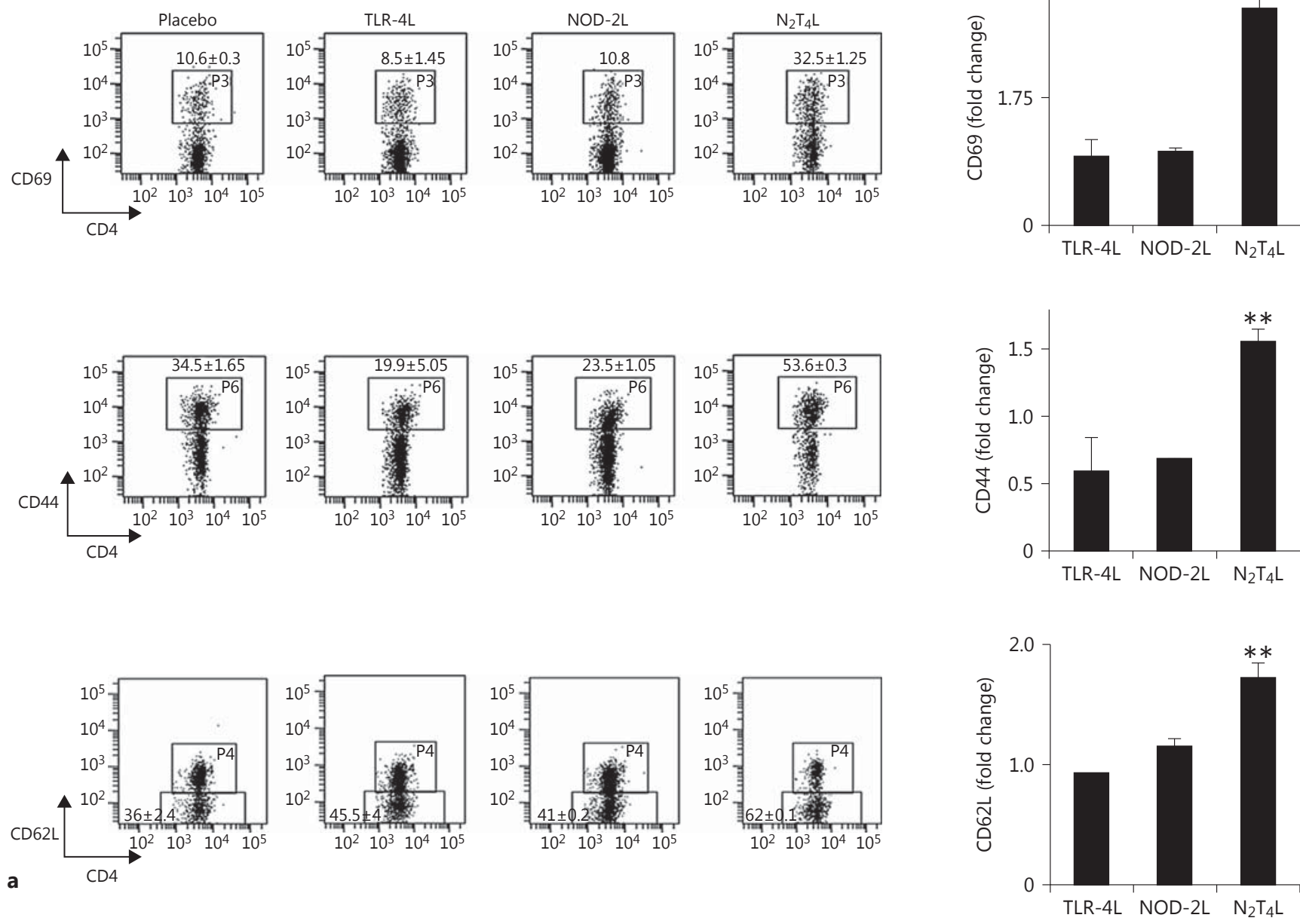

Fig. 6. Immunotherapy employing $\mathrm{N}_{2} \mathrm{~T}_{4} \mathrm{~L}$ chiefly evokes a memory Th1 response. $M t b$-infected animals were treated with $\mathrm{N}_{2} \mathrm{~T}_{4} \mathrm{~L}$ and control groups with NOD-2L, TLR-4L or placebo. After 45 days, lymphocytes were isolated and stained for the surface phenotype of CD69, CD44 and CD62L on CD4 T cells (a) and CD8 T cells (b). Dot plots depict percentages of cells (left panels) and bar diagrams illustrate the fold changes relative to placebo (right panels). c Intracellular expression of IFN- $\gamma$ by CD4 and CD8 T cells. Dot plots (left panels) and bar diagrams (right panels) depict percentages of IFN- $\gamma$-positive cells. d IFN- $\gamma$ expression was quanti-

ther, $\mathrm{N}_{2} \mathrm{~T}_{4} \mathrm{~L}$ treatment displayed a substantial decline in granulomatous lesions and perivascular and peribronchiolar cuffing in the histopathological samples. The lungs were less consolidated with more normal alveolar structures (fig. 7b). Excitingly, lungs resected from the mice administered with $\mathrm{N}_{2} \mathrm{~T}_{4} \mathrm{~L}$ revealed significant $(\mathrm{p}<0.001)$ fied in the lungs of $M t b$-challenged mice by RT-qPCR, and mRNA expression was normalized with control actin. For an antigen-specific response, lymphocytes were stimulated in vitro with PPD for $48 \mathrm{~h}$. Later, cells were monitored for the release of IFN- $\gamma$ in supernatants by ELISA (e) and the intracellular expression of TNF- $\alpha$ by flow cytometry on CD4-gated T cells (f). Numbers above insets indicate the MFI/percentage of TNF- $\alpha$-positive CD4 T cells. $\mathbf{g}$ Proliferation by ${ }^{3} \mathrm{H}$-thymidine incorporation. Data (\%) represented as bar diagrams are mean \pm SEM from 2 independent experiments with 6 mice/group. ${ }^{*} \mathrm{p}<0.05,{ }^{* *} \mathrm{p}<0.01,{ }^{* * *} \mathrm{p}<0.001$.

(For figure 6b-g see next pages.) 


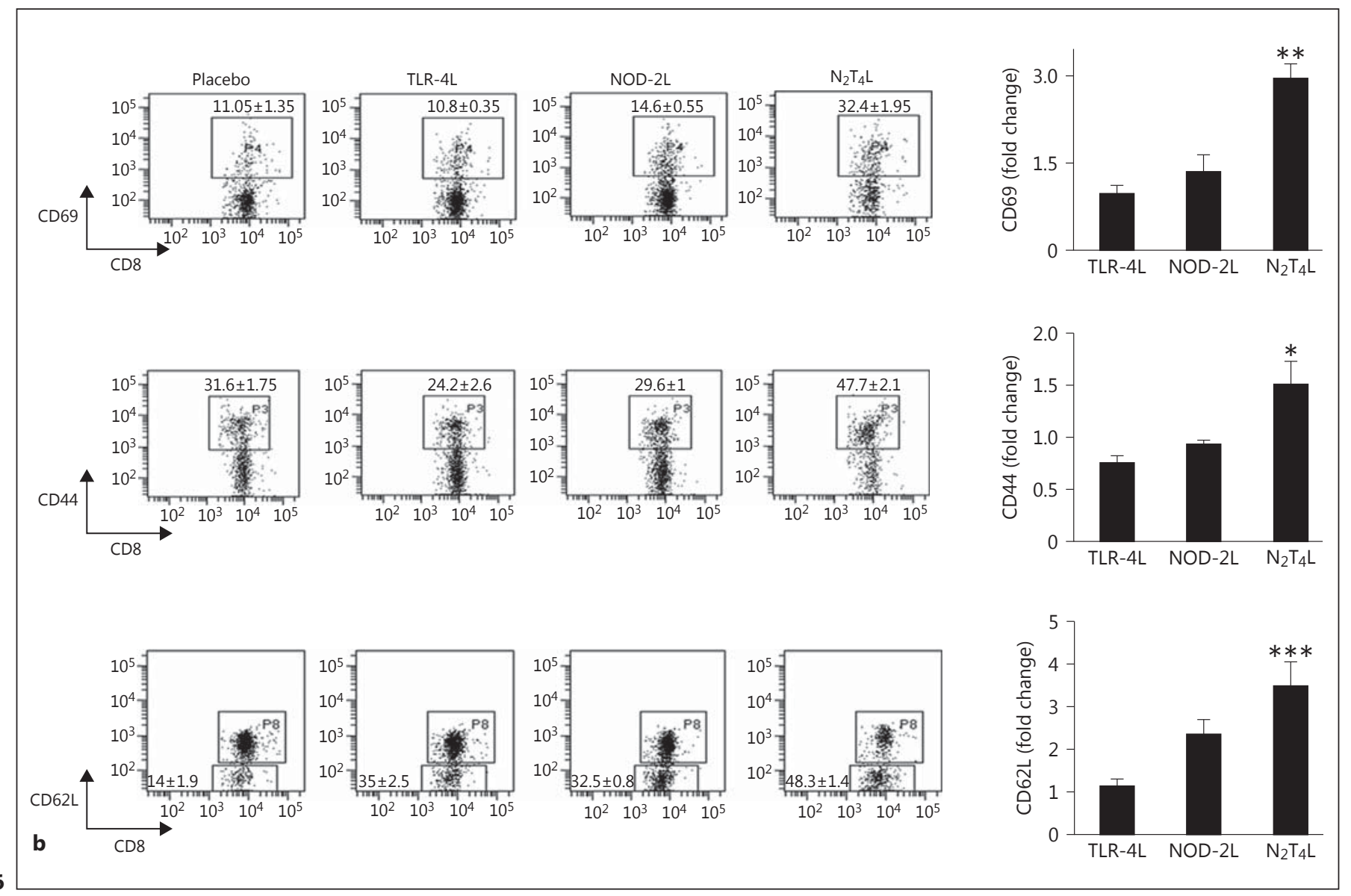

vival of the treated mice. We did not observe any mortality in this group. This shows that the dose of $\mathrm{N}_{2} \mathrm{~T}_{4}$ used in the experiments elicited a response that was not lethal for animals that could lead to their death.

\section{$\mathrm{N}_{2} \mathrm{~T}_{4}$-Drug Adjunct Therapy Significantly Boosts in} vivo Drug Efficacy in Restraining the Growth of Mtb

Finally, we demonstrated that a combination therapy employing $\mathrm{N}_{2} \mathrm{~T}_{4} \mathrm{~L}$ significantly $(\mathrm{p}<0.001)$ potentiated the efficacy of INH in reducing the $M t b$ load in the lungs of infected mice (fig. 7e). Excitingly, adjunct therapy involving $\mathrm{N}_{2} \mathrm{~T}_{4} \mathrm{~L}$ caused a 5 -fold reduction in the quantity of $\mathrm{INH}$, demonstrated by being able to curtail the dose of INH from 25 to $5 \mathrm{mg} / \mathrm{kg}$ of body weight (BW). It is worth mentioning that administration of $5 \mathrm{mg}$ of INH in conjunction with $\mathrm{N}_{2} \mathrm{~T}_{4} \mathrm{~L}$ imparted a considerably $(\mathrm{p}<0.001)$ greater decline in CFU than $25 \mathrm{mg}$ of INH only. These results establish the critical role of $\mathrm{N}_{2} \mathrm{~T}_{4}$ in not only reducing the dose of anti-TB drugs but also markedly increasing their killing efficiency.

\section{Discussion}

Despite the availability of highly effective drug regimens against $\mathrm{TB}$, many patients fail to comply with the treatment [25]. The threat posed by TB is further compounded by the emergence of the AIDS pandemic and multidrug-resistant, extensively drug-resistant and totally drug-resistant $M t b[1]$.

Innate immunity plays a pivotal role in imparting protection against pathogens $[26,27]$. It may also reinvigorate host immunity suppressed by anti-TB drugs [28-30]. Thus, we designed a simple and elegant approach of strengthening host immunity by potentiating DC function by delivering signals through $\mathrm{N}_{2} \mathrm{~T}_{4}$. We studied its role in vitalizing the potency of TB drugs to kill $M t b$.

Delivering signals through $\mathrm{N}_{2} \mathrm{~T}_{4}$ led to the emergence of the following major findings: (1) the enhanced activation of DCs, (2) the augmented ability of DCs to help T cells, (3) enhanced autophagy, NO release and a decline in the survival of the bacteria, (4) improved migration to- 


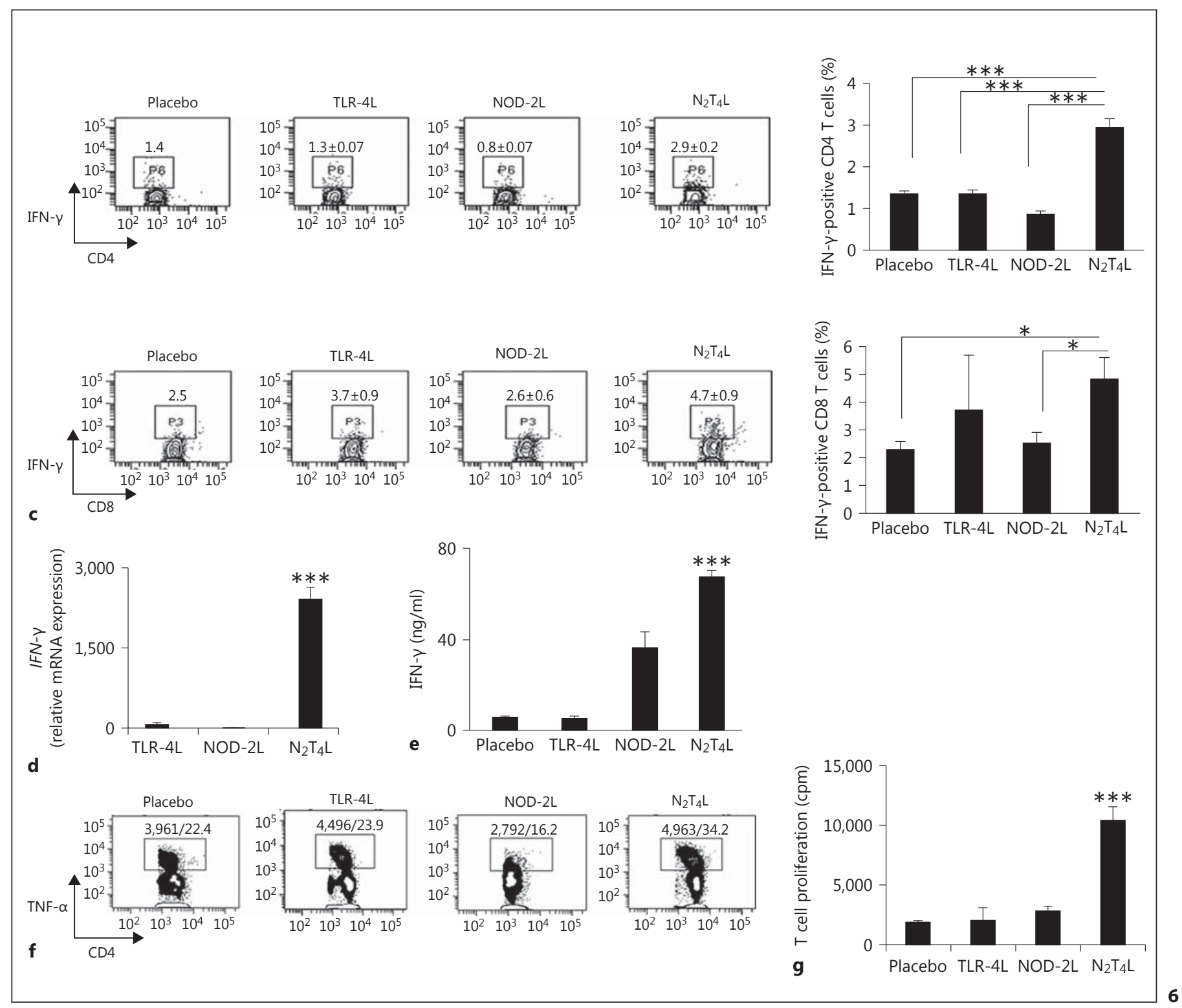

wards lymph nodes due to increased CCR7 expression, (5) increased in vivo effector T cell memory response and release of IFN- $\gamma$ and TNF- $\alpha$ and (6) a reduction in the drug dose and an improvement of the in vitro and in vivo potency of the drugs in killing $M t b$. DCs are a bridging component of innate and adaptive immunity [31]. Consequently, we thought that targeting DCs through $\mathrm{N}_{2} \mathrm{~T}_{4}$ might be an appropriate immunotherapeutic approach in evoking host immunity against $M t b$.

We observed that $\mathrm{N}_{2} \mathrm{~T}_{4}$. DCs showed robust production of the cytokines IL- 6 and IL-12. Mice deficient in IL12 p40 are highly susceptible to $M t b$ infection $[24,32]$.
$\mathrm{N}_{2} \mathrm{~T}_{4}$.DCs also showed enhanced competence in activating $\mathrm{T}$ cells. Furthermore, migration of DCs to lymph nodes is a crucial step for initiating the activation of $\mathrm{T}$ cells. $\mathrm{N}_{2} \mathrm{~T}_{4}$ treatment showed substantial increase in the pool of $M t b$-loaded DCs in the DLNs. Importantly, $\mathrm{N}_{2} \mathrm{~T}_{4}$ triggering had no adverse effect on the viability of DCs (online suppl. fig. S3). It is important to mention that $\mathrm{N}_{2} \mathrm{~T}_{4}$ triggering enhances the bactericidal activity of macrophages as well (online suppl. fig. S4).

$\mathrm{T}$ cells require cognate interaction with DCs for their activation, proliferation and differentiation. However, recently, the contribution of innate receptors has been 


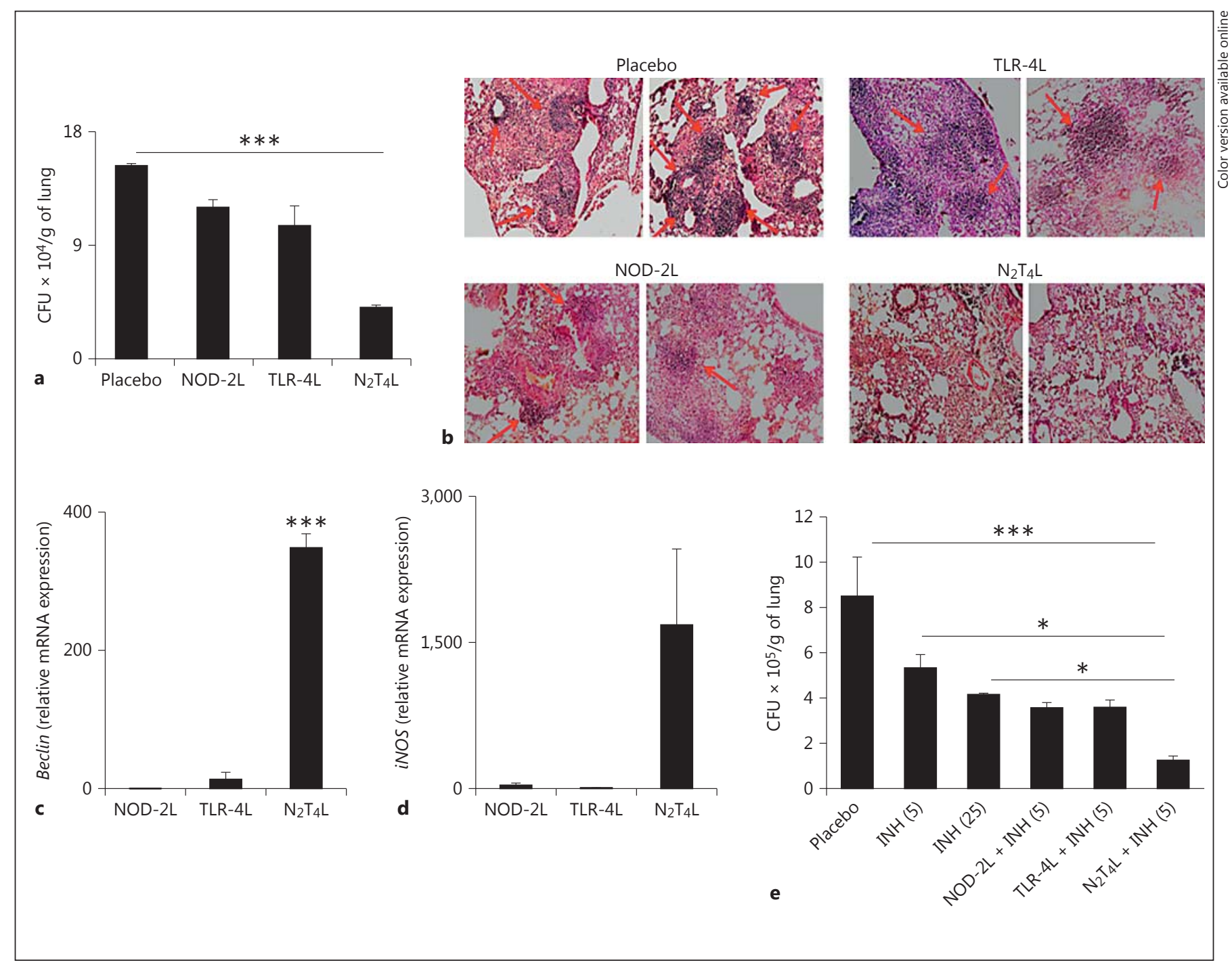

Fig. 7. Immunization with $\mathrm{N}_{2} \mathrm{~T}_{4} \mathrm{~L}$ successfully imparts protection against $M t b$ and significantly bolsters INH potency to kill the $M t b$. Mice infected with $M t b$ were treated with $\mathrm{N}_{2} \mathrm{~T}_{4} \mathrm{~L}$ and control groups with NOD-2L, TLR-4L or placebo. a Later, animals were sacrificed, and the $M t b$ load in the lungs was enumerated by CFU plating. Data are represented as CFU/g of lung ( $\mathrm{n}=6$ animals/ group). b Photomicrographs of stained lung sections (arrows indicate granulomas). HE. $\times 40 . \mathbf{c}, \mathbf{d}$ Beclin and $i N O S$ in the lungs of

reported in clonal expansion of the effector $\mathrm{T}$ cells, independent of the occupancy of $\mathrm{T}$ cell receptors by the MHCII peptide [33]. Importantly, $M t b$-challenged mice treated with $\mathrm{N}_{2} \mathrm{~T}_{4} \mathrm{~L}$ showed substantial $\mathrm{T}$ cell proliferation, with an abundant release of IFN- $\gamma$ and TNF- $\alpha$ [34, 35]. In addition, it augmented the effector T cell memory response. Furthermore, the growth of $M t b$ was meticulously restricted even after 45 days of infection.
$M t b$-challenged mice were quantified by RT-qPCR, and mRNA expression was normalized with control actin. e $M t b$-infected mice were treated with $\mathrm{N}_{2} \mathrm{~T}_{4} \mathrm{~L}$ along with adjunct therapy using INH. The control groups were administered NOD-2L, TLR-4L, NOD$2 \mathrm{~L}+\mathrm{INH}$, TLR-4L + INH or placebo. Figures in parentheses indicate 5 and $25 \mathrm{mg} / \mathrm{kg}$ BW of INH administered bimonthly to mice. Data are representative of 2 independent experiments $(n=3$ mice/ group) and expressed as mean \pm SD. ${ }^{*} \mathrm{p}<0.05,{ }^{* * *} \mathrm{p}<0.001$.

Autophagy has been reported as exhibiting a dual role in $M t b$ protection. It targets the antigen to lysosomes for degradation and delivers antimicrobial peptides to $M t b$ harboring compartments. Simultaneously, it prevents an excessive inflammatory reaction in the host $[36,37]$. In addition, it enhances the antigen-presenting ability of DCs to $\mathrm{T}$ cells [38]. Importantly, $\mathrm{N}_{2} \mathrm{~T}_{4}$. DCs showed an augmentation of autophagy and NO release and a signif- 
icant contribution to the reduction of the intracellular survival of $M t b$. The expression of Beclin and iNOS in the lungs of $M t b$-challenged mice treated with $\mathrm{N}_{2} \mathrm{~T}_{4} \mathrm{~L}$ also suggests autophagy and NO release to be a mechanism for conferring protection against $M t b$.

The current TB regime is extremely efficient, but the major impediment is the long duration of 6 months, which inevitably gives rise to several side effects [39]. Still, the remarkable potency of TB drugs cannot be ignored. Henceforth, very pragmatically, we targeted $\mathrm{N}_{2} \mathrm{~T}_{4}$ to reinvigorate host immunity, and the outcome was some control of the survival of $M t b$. Intriguingly, a significant increase in mycobacterial mortality was noted when $M t b$ infected DCs were treated with RIF in conjunction with $\mathrm{N}_{2} \mathrm{~T}_{4}$ agonists. We further confirmed these results by administering INH in combination with $\mathrm{N}_{2} \mathrm{~T}_{4} \mathrm{~L}$ in $M t b$-infected mice in vivo. Strikingly, animals inoculated with a 5 -fold lesser dose (5 $\mathrm{mg} / \mathrm{kg} \mathrm{BW}$ ) of INH bimonthly in conjunction with $\mathrm{N}_{2} \mathrm{~T}_{4} \mathrm{~L}$ showed a significant reduction in the bacterial load in the lungs, compared to the recommended daily dose of $25 \mathrm{mg} / \mathrm{kg} \mathrm{BW}$ of INH only [40]. So this approach significantly reduced the dose of the drug. There is another fundamental benefit to INH- $\mathrm{N}_{2} \mathrm{~T}_{4}$ adjunct therapy, since the drug would kill the replicating $M t b$ and $\mathrm{N}_{2} \mathrm{~T}_{4} \mathrm{~L}$ would enhance host immunity for eliminating a nonreplicating, quiescent mycobacterium. So the $\mathrm{INH}-\mathrm{N}_{2} \mathrm{~T}_{4}$ strategy may not only be advantageous in overcoming the side effects because of the lower drug dosage, it also alerts the host immunity to restrain the emergence of drug resistance in $M t b$. Implementing this innovative drug $+\mathrm{N}_{2} \mathrm{~T}_{4}$ therapy may be a prudent approach in the future to effectively treat TB patients.

\section{Acknowledgements}

We are grateful to Dr. B.N. Dutta, former Professor of the Postgraduate Institute of Medical Education and Research, Chandigarh, India, for histopathological analysis. N.K. received a fellowship from the Department of Biotechnology, A.V. and S.P. from the CSIR and M.A. from the Department of Science and Technology, India. The study was supported by the Council of Scientific and Industrial Research (CSIR), New Delhi, India.

\section{References}

1 Gandhi NR, Nunn P, Dheda K, Schaaf HS, Zignol M, van Soolingen D, Jensen P, Bayona J: Multidrug-resistant and extensively drug-resistant tuberculosis: a threat to global control of tuberculosis. Lancet 2010;375:1830-1843.

$\checkmark 2$ Andersen P, Doherty TM: The success and failure of BCG - implications for a novel tuberculosis vaccine. Nat Rev Microbiol 2005;3: 656-662.

3 Howitt MR, Garrett WS: A complex microworld in the gut: gut microbiota and cardiovascular disease connectivity. Nat Med 2012; 18:1188-1189.

4 Iida N, Dzutsev A, Stewart CA, Smith L, Bouladoux N, Weingarten RA, Molina DA, Salcedo R, Back T, Cramer S, Dai RM, Kiu H, Cardone M, Naik S, Patri AK, Wang E, Marincola FM, Frank KM, Belkaid Y, Trinchieri G Goldszmid RS: Commensal bacteria control cancer response to therapy by modulating the tumor microenvironment. Science 2013;342: 967-970.

$\checkmark 5$ Pyonteck SM, Akkari L, Schuhmacher AJ, Bowman RL, Sevenich L, Quail DF, Olson OC, Quick ML, Huse JT, Teijeiro V, Setty M, Leslie CS, Oei Y, Pedraza A, Zhang J, Brennan CW, Sutton JC, Holland EC, Daniel D, Joyce JA: CSF-1R inhibition alters macrophage polarization and blocks glioma progression. Nat Med 2013;19:1264-1272.
76 Suvas S, Singh V, Sahdev S, Vohra H, Agrewala JN: Distinct role of CD80 and CD86 in the regulation of the activation of $\mathrm{B}$ cell and $\mathrm{B}$ cell lymphoma. J Biol Chem 2002;277:77667775 .

7 Akira S, Uematsu S, Takeuchi O: Pathogen recognition and innate immunity. Cell 2006; 124:783-801.

$>8$ Akira S, Takeda K, Kaisho T: Toll-like receptors: critical proteins linking innate and acquired immunity. Nat Immunol 2001;2:675680.

$\checkmark 9$ Fremond CM, Yeremeev V, Nicolle DM, Jacobs M, Quesniaux VF, Ryffel B: Fatal Mycobacterium tuberculosis infection despite adaptive immune response in the absence of MyD88. J Clin Invest 2004;114:1790-1799.

10 Divangahi M, Mostowy S, Coulombe F, Kozak R, Guillot L, Veyrier F, Kobayashi KS, Flavell RA, Gros P, Behr MA: Nod2-deficient mice have impaired resistance to Mycobacterium tuberculosis infection through defective innate and adaptive immunity. J Immunol 2008;181:7157-7165.

-11 Pandey AK, Yang Y, Jiang Z, Fortune SM, Coulombe F, Behr MA, Fitzgerald KA, Sassetti CM, Kelliher MA: NOD2, RIP2 and IRF5 play a critical role in the type I interferon response to Mycobacterium tuberculosis. PLoS Pathog 2009;5:e1000500.
12 Lupfer C, Thomas PG, Kanneganti TD: Nucleotide oligomerization and binding domain 2 -dependent dendritic cell activation is necessary for innate immunity and optimal CD8+ $\mathrm{T}$ cell responses to influenza A virus infection. J Virol 2014;88:8946-8955.

13 World Health Organization: WHO recommendations, 2007.

-14 Buettner M, Meinken C, Bastian M, Bhat R, Stossel E, Faller G, Cianciolo G, Ficker J, Wagner M, Rollinghoff M, Stenger S: Inverse correlation of maturity and antibacterial activity in human dendritic cells. J Immunol 2005; 174:4203-4209.

15 Marina-Garcia N, Franchi L, Kim YG, Hu Y, Smith DE, Boons GJ, Nunez G: Clathrin- and dynamin-dependent endocytic pathway regulates muramyl dipeptide internalization and NOD2 activation. J Immunol 2009; 182:43214327.

16 Coulombe F, Divangahi M, Veyrier F, de Leseleuc L, Gleason JL, Yang Y, Kelliher MA, Pandey AK, Sassetti CM, Reed MB, Behr MA: Increased NOD2-mediated recognition of Nglycolyl muramyl dipeptide. J Exp Med 2009; 206:1709-1716.

17 Needham BD, Carroll SM, Giles DK, Georgiou G, Whiteley M, Trent MS: Modulating the innate immune response by combinatorial engineering of endotoxin. Proc Natl Acad Sci USA 2013;110:1464-1469. 
18 Bohannon JK, Hernandez A, Enkhbaatar P, Adams WL, Sherwood ER: The immunobiology of Toll-like receptor 4 agonists: from endotoxin tolerance to immunoadjuvants. Shock 2013;40:451-462.

19 Lutz MB, Kukutsch N, Ogilvie AL, Rössner S, Koch F, Romani N, Schuler G: An advanced culture method for generating large quantities of highly pure dendritic cells from mouse bone marrow. J Immunol Methods 1999;223:77-92.

20 Barth S, Glick D, Macleod KF: Autophagy: assays and artifacts. J Pathol 2010;221:117124.

21 MacMicking JD, North RJ, LaCourse R, Mudgett JS, Shah SK, Nathan CF: Identification of nitric oxide synthase as a protective locus against tuberculosis. Proc Natl Acad Sci USA 1997;94:5243-5248.

-22 Riol-Blanco L, Sanchez-Sanchez N, Torres A, Tejedor A, Narumiya S, Corbi AL, SanchezMateos P, Rodriguez-Fernandez JL: The chemokine receptor CCR7 activates in dendritic cells two signaling modules that independently regulate chemotaxis and migratory speed. J Immunol 2005;174:4070-4080.

23 Seth S, Oberdorfer L, Hyde R, Hoff K, Thies V, Worbs T, Schmitz S, Forster R: CCR7 essentially contributes to the homing of plasmacytoid dendritic cells to lymph nodes under steady-state as well as inflammatory conditions. J Immunol 2011;186:3364-3372.

-24 Khader SA, Partida-Sanchez S, Bell G, JelleyGibbs DM, Swain S, Pearl JE, Ghilardi N, Desauvage FJ, Lund FE, Cooper AM: Interleukin $12 \mathrm{p} 40$ is required for dendritic cell migration and $\mathrm{T}$ cell priming after Mycobacterium tuberculosis infection. J Exp Med 2006;203: 1805-1815.
25 Munro SA, Lewin SA, Smith HJ, Engel ME, Fretheim A, Volmink J: Patient adherence to tuberculosis treatment: a systematic review of qualitative research. PLoS Med 2007;4:e238.

-26 Natarajan K, Kundu M, Sharma P, Basu J: Innate immune responses to $M$. tuberculosis infection. Tuberculosis (Edinb) 2011;91:427431.

27 Huynh KK, Joshi SA, Brown EJ: A delicate dance: host response to mycobacteria. Curr Opin Immunol 2011;23:464-472.

28 Paunescu E: In vivo and in vitro suppression of humoral and cellular immunological response by rifampicin. Nature 1970;228:11881190.

29 Bellahsene A, Forsgren A: Effect of rifampin on the immune response in mice. Infect Im mun 1980;27:15-20.

30 Floersheim GL: Suppression of cellular immunity in vivo by rifampicin. Experientia 1973;29:1545-1546.

31 Steinman RM, Hemmi H: Dendritic cells: translating innate to adaptive immunity. Curr Top Microbiol Immunol 2006;311:17-58.

32 Holscher C, Atkinson RA, Arendse B, Brown N, Myburgh E, Alber G, Brombacher F: A protective and agonistic function of IL-12p40 in mycobacterial infection. J Immunol 2001; 167:6957-6966.

33 O’Donnell H, Pham OH, Li LX, Atif SM, Lee SJ, Ravesloot MM, Stolfi JL, Nuccio SP, Broz P, Monack DM, Baumler AJ, McSorley SJ: Toll-like receptor and inflammasome signals converge to amplify the innate bactericidal capacity of T helper 1 cells. Immunity 2014; 40:213-224.
34 Kaufmann SH: How can immunology contribute to the control of tuberculosis? Nat Rev Immunol 2001;1:20-30.

-35 Flynn JL, Chan J: Immunology of tuberculosis. Annu Rev Immunol 2001;19:93-129.

36 Jo EK: Innate immunity to mycobacteria: vitamin D and autophagy. Cell Microbiol 2010; 12:1026-1035.

37 Castillo EF, Dekonenko A, Arko-Mensah J, Mandell MA, Dupont N, Jiang S, DelgadoVargas M, Timmins GS, Bhattacharya D, Yang H, Hutt J, Lyons CR, Dobos KM, Deretic $\mathrm{V}$ : Autophagy protects against active tuberculosis by suppressing bacterial burden and inflammation. Proc Natl Acad Sci USA 2012; 109:E3168-E3176.

38 Jagannath C, Lindsey DR, Dhandayuthapani S, Xu Y, Hunter RL Jr, Eissa NT: Autophagy enhances the efficacy of BCG vaccine by increasing peptide presentation in mouse dendritic cells. Nat Med 2009;15:267-276.

39 Manabe YC, Bishai WR: Latent Mycobacterium tuberculosis - persistence, patience, and winning by waiting. Nat Med 2000;6:13271329.

40 Wang F, Sambandan D, Halder R, Wang J, Batt SM, Weinrick B, Ahmad I, Yang P, Zhang Y, Kim J, Hassani M, Huszar S, Trefzer C, Ma Z, Kaneko T, Mdluli KE, Franzblau S, Chatterjee AK, Johnsson K, Mikusova K, Besra GS, Futterer K, Robbins SH, Barnes SW, Walker JR, Jacobs WR Jr, Schultz PG: Identification of a small molecule with activity against drug-resistant and persistent tuberculosis. Proc Natl Acad Sci USA 2013; 110:E2510-E2517. 